\title{
Sağlık Bilimleri Öğrencilerinde Obezite Ön Yargısı ve İlişkili Etmenler
}

\author{
Ezgi BELLİKCİ KOYU ๑®, Yasemin KARAAĞAÇ ๑, Şafak MİÇOOĞULLARI ๑ \\ İzmir Kâtip Çelebi Üniversitesi, Sağlık Bilimleri Fakültesi, Beslenme ve Diyetetik Bölümü, İzmir, Türkiye
}

Bu makaleye yapılacak atıf: Bellikci Koyu E, Karaağaç Y, Miçooğulları Ş. Sağlık Bilimleri Öğrencilerinde Obezite Ön Yargısı ve İlişkili Etmenler. Türk Diyab Obez 2020;3: 260-269.

ÖZ

Amaç: Bu araştırma, sağlık bilimleri fakültesi öğrencilerinin obezite ön yargı düzeylerini belirlemek ve öğrencilerde obezite ön yargısı ile ilişkili etmenleri araştırmak amacıyla planlanmıştır.

Gereç ve Yöntemler: Tanımlayıcı ve kesitsel tipteki bu araştırma bir devlet üniversitesinin sağlık bilimleri fakültesinde öğrenim görmekte olan 756 öğrenci ile yürütülmüştür. Veriler sosyo-demografik özelliklerin, yaşam tarzı alışkanlıklarının, antropometrik ölçümlerin, GAMS-27 Obezite ön yargı ölçeği'nin ve Yeme Tutum Testi-40'ın yer aldığı bir anket formu kullanılarak toplanmıștır. Verilerin analizinde SPSS 26.0 istatistik paket programı kullanılmış ve anlamlılık düzeyi p<0,05 olarak kabul edilmiştir.

Bulgular: Araştırmaya katılan öğrencilerin yaş ortalaması 20,07£1,36 yıldır. GAMS-27 obezite ön yargı ölçeği puanına göre öğrencilerin \%53,6'sı obeziteye karşı ön yargıl1, \%41,1'i ön yargıya eğilimli ve \%5,3’ü ön yargısız bulunmuştur. Obezite ön yargısı bölümlere göre değerlendirildiğinde, beslenme ve diyetetik öğrencilerinin obezite ön yargısı, hemşirelik bölümü ve fizyoterapi ve rehabilitasyon bölümü öğrencilerine göre daha yüksek bulunmuştur ( $p<0,001)$. Öğrenciler beden kütle indekslerine göre sınıflandırıldığında, obezitesi olan öğrencilerin diğer öğrencilere kıyasla obezite ön yargı puanlarının daha düşük olduğu belirlenmiştir ( $\mathrm{p}=0,001)$. Benzer şekilde, yaşamında, kendini şişman bulduğu bir dönemi olan öğrencilerde, böyle bir dönemi olmayanlara göre ön yargı ölçeği puanlarının anlamlı şekilde daha düşük olduğu saptanmıştır ( $\mathrm{p}=0,005)$.

Sonuç: Sağlık bilimlerinde, özellikle beslenme ve diyetetik bölümünde öğrenim görmekte olan öğrencilerin büyük çoğunluğunun obeziteye karşı ön yargılı veya ön yargıya eğilimli olduğu saptanmıștır. Öğrencilerin gelecekte etkin ve ön yargısız bir sağlık hizmeti sunabilmeleri için ders programlarına obezite ön yargılarını azaltmaya yönelik uygulamaların eklenmesi önerilebilir.

Anahtar Sözcükler: Obezite, A ̈̆ırlık ön yargısı, Sosyal stigma

\section{Obesity Prejudice and Related Factors Among Health Sciences Students}

\begin{abstract}
Aim: This research was planned to determine the obesity prejudice levels of the faculty of health sciences students and to investigate factors related to obesity prejudice in students.

Material and Methods: This descriptive and cross-sectional study was carried out with 756 students studying at the faculty of health sciences of a state university. The data were collected using a questionnaire including sociodemographic characteristics, lifestyle habits, anthropometric measurements, GAMS-27 Obesity Prejudice Scale, and Eating Attitude Test-40. SPSS 26.0 statistical software was used to analyze the data and the significance level was accepted as $\mathrm{p}<0.05$.

Results: The mean age of the students participating in this research was $20.07 \pm 1.36$ years. According to the GAMS-27 Obesity Prejudice Scale, $53.6 \%$ of students were prejudiced against obesity, $41.1 \%$ were inclined to prejudice and $5.3 \%$ were unprejudiced. When obesity prejudice was evaluated by departments, obesity prejudice was found higher among nutrition and dietetic students compared to nursing and physiotherapy and rehabilitation students $(\mathrm{p}<0.001)$. According to body mass index classification, obesity prejudice scale scores were determined lower in students with obesity compared to other students $(\mathrm{p}=0.001)$. Similarly, students who accepted themselves as obese in a period throughout their life had significantly lower prejudice scale scores than those without such a period ( $\mathrm{p}=0.005)$.
\end{abstract}

ORCID: Ezgi Bellikci Koyu / 0000-0001-5279-2394, Yasemin Karaağaç / 0000-0002-2757-2485, Şafak Miçooğulları / 0000-0003-1711-906X 
Conclusion: The majority of students studying in the health sciences, especially in the nutrition and dietetics department were either prejudiced or inclined to prejudice. It may be suggested to add practices to the curriculum to reduce obesity prejudice in order to provide an effective and prejudice-free healthcare service in the future.

Key Words: Obesity, Weight prejudice, Social stigma

\section{GİRIŞ}

Vücutta anormal yağ birikimi olarak tanımlanan obezite, artan prevalansı ve yol açtığı morbidite ve mortalite oranları ile çağımızın en önemli hastalıklarından birisidir (1). Obezitenin neden olduğu fizyolojik sorunlar iyi bilinmekle birlikte, madalyonun diğer tarafinda vücut ağırlığ fazla olduğu için damgalanan ve bu damgalanmanın yol açtığı sorunlarla mücadele etmek durumunda kalan bireyler bulunmaktadır. $\mathrm{Bu}$ nedenle, obezitenin kendisi kadar "obezitenin nasıl algılandığı" da önemli bir konudur. Türkçe'ye genellikle ağırlık ön yargısı olarak çevrilmiş olan "weight bias", vücut ağırlığından dolayı bireylere yönelik olumsuz tutum ve inanışlara sahip olma şeklinde tanımlanmaktadır (2,3). Bu olumsuz tutumlar, vücut ağırlığ fazla bireylere yönelik klișeler veya ön yargılarla kendini gösterir ve ön yargıya maruz kalan bireye yapıştırılmış olan sosyal bir işaret ya da etiketlenme durumu olan damgalamaya (stigma) yol açabilir (2).

Obezitesi olan bireylere yönelik ayrımcılık ve dışlamaya neden olabilen damgalamanın, çeşitli biyolojik, psikolojik ve sosyal sorunlar ile ilişkili olduğu gösterilmiştir. Konuyu inceleyen sistematik derlemelerde, vücut ağırlığına yönelik damgalamanın bireyler için bir stres faktörü olduğu; obezite, diyabet, yeme bozuklukları, beden imgesinden memnuniyetsizlik, anksiyete, depresyon, anti-sosyal davranış ve madde kullanımı ile pozitif ilişkili olduğu bildirilmiştir $(4,5)$. Bunların yanı sıra, vücut ağırlığına yönelik damgalamanın oksidatif stres, kortizol ve C-reaktif protein (CRP) düzeyleri gibi biyolojik göstergelerle de ilişkisi gösterilmiştir (5). Obezite ön yargısına maruz kalan bireylerde damgalama içselleştirildiğinde bu ilişkilerin daha da kuvvetlenebileceği, sosyal etkileşimler ve yaşam kalitesi üzerine olan olumsuz etkilerin artabileceği bildirilmiştir (4).

Yapılan çalışmalar, obeziteye ilişkin damgalamaların obezite prevalansına eşlik ederek artmakta olduğunu göstermektedir (6,7). Almanya'da yapılan bir çalışmada, vücut ağırlığına yönelik olan ayrımcılığın \%5,6-38,0 arasında olduğu bildirilmiştir (8). Konuya ilişkin yürütülen bir meta-analizde, algılanan ayrımcilık oranının birinci derece obezitesi [Beden Kütle İndeksi (BKİ):30-35 kg/ $\mathrm{m}^{2}$ ] olan bireylerde $\% 19,2$ olduğu, BKİ değeri arttıkça algılanan ayrımcilı̆̆ın arttığı ve ikinci derece ve üzerinde obezitesi olan bireylerde $\% 41,8$ 'e ulaştığ gösterilmiştir (9).
Obeziteye ilişkin ön yargı ve olumsuz tutumlar eğitim, iş, sağlık, medya gibi hayatın farklı alanlarında gözlenebilmektedir (3,9-13). Sağlık çalışanlarının hastalarına yardımcı olma konusundaki tüm çabalarına rağmen, açık ya da örtük ön yargilar nedeniyle obezitesi olan bireyler zaman zaman olumsuz tutumlara maruz kalabilmekte, vücut ağırlıklarından dolayı kişisel olarak suçlanabilmekte, tedaviye uyum göstermeyen, tembel, öz-kontrol ve irade eksikliği olan bireyler olarak etiketlenebilmektedir (14). Damgalamanın, bakım kalitesini ve hatta bakım süresini azaltabileceği bildirilmiştir. Bu olumsuz deneyimlerin bir sonucu olarak hastalarda sağlık çalışanına güvensizlik gelişebilmekte, sağlık kuruluşuna gitmeme, randevularını kaçırma veya tıbbi tedaviye uyumsuzluk gibi davranışlar görülebilmekte ve durum karşılıklı bir döngüye girmektedir (11).

Sağlık ile ilişkili bölümlerde eğitim alan üniversite öğrencileri, obezitesi olan bireylere gelecekte bakım ve hizmet verecek, onlara danışmanlık sağlayacak grubu oluşturmaktadır. $\mathrm{Bu}$ nedenle, bu bölümlerde okuyan öğrencilerin obezite ön yargı düzeylerinin ve ön yargı ile ilişkili faktörlerin belirlenmesi önemlidir. Böylelikle obeziteye yönelik olumsuz tutum ve davranışları azaltabilmek, ortadan kaldırabilmek veya olumluya dönüştürebilmek için gerekli müdahalelerin planlanması ve uygulanması söz konusu olabilir. Ülkemizde konuya ilişkin çeşitli araştırmalar yürütülmüş olmakla birlikte, çalışmalar çoğunlukla ebelik ve hemşirelik bölümü öğrencilerine odaklanmıştır (15-17). Bu nedenle, bu araştırmada sağlık alanında farklı mesleklere yönelik eğitim alan sağlık bilimleri fakültesi öğrencilerinin obezite ön yargı düzeylerinin belirlenmesi ve obezite ön yargısı ile ilişkili etmenlerin ortaya çıkarılması amaçlanmıştır.

\section{GEREÇ ve YÖNTEMLER}

\section{Araştırmanın Tipi ve Zamanı}

Kesitsel ve tanımlayıcı nitelikte planlanan bu araştırma Aralık 2019-Mart 2020 tarihleri arasında gerçekleştirilmiştir.

\section{Evren ve Örneklem}

Araştırmanın evrenini bir devlet üniversitesinin sağlik bilimleri fakültesinde 2019-2020 eğitim öğretim yılında öğrenim görmekte olan öğrenciler oluşturmuştur. Araştırma kapsamında tam sayım yöntemi ile evrenin tümüne 
$(\mathrm{n}=1214)$ ulaşılması hedeflenmiş olup, çalışmaya katılmayı kabul eden ve soruları eksiksiz yanıtlayan 756 kişi ile çalışma tamamlanmıștır.

\section{Etik Onay/Hasta Onamı}

Araştırmanın yapılması için gerekli izinler İzmir Kâtip Çelebi Üniversitesi Sosyal Araştırmalar etik kurulundan 07.11.2019 tarihinde alınmıştır (Etik kurul No: 2019.08.04). Etik kurul izninin ardından araștırmanın yapıldı ğ 1 kurumun dekanlığına başvurulmuş ve 02.12.2019 tarihinde kurum izni alınmıştır. Araştırmaya katılacak bireylere öncelikle araştırma hakkında kısa bir bilgi verilmiş, bilgilendirilmiş gönüllü onam formunu imzalamaları halinde araştırmaya dâhil edilmiştir. Araştırma, Helsinki Bildirgesine uygun olarak yürütülmüsstür.

\section{Veri Toplama Araçları}

Araştırma verileri önceden yapılandırılmış bir anket formu ile toplanmıştır. Anket formu sosyo-demografik özelliklerin, yaşam tarzı alışkanlıkları ve beden algısının, antropometrik ölçümlerin, GAMS-27 Obezite ön yarg1 ölçeği'nin ve Yeme Tutum Testi-40'ın (YTT-40) sorgulandığı beş bölümden oluşmuştur. Antropometrik ölçüm olarak vücut ağırlığı $(\mathrm{kg})$ ve boy $(\mathrm{cm})$ sorgulanmış, vücut ağırlığ cinsinden karesine bölünerek BKİ değerleri hesaplanmıştır. BKİ'nin sınıflandırmasında Dünya Sağlık Örgütü’nün (WHO) sınıflaması kullanılmıştır (18).

\section{GAMS-27 Obezite Ön Yargı Ölçeği}

Ercan ve ark. tarafından 2015 yılında geliştirilen GAMS27 Obezite ön yargı ölçeği 27 maddeden oluşmaktadır (19). Ölçekten en az 27 en fazla 135 puan alınabilmektedir. Ölçek; "kesinlikle katıllyorum", "katılıyorum", "karars1zım", "katılmıyorum" ve "kesinlikle katılmıyorum" şeklinde 5 'li likert derecelendirme sistemine göre derecelendirilmiştir. Ölçekte yer alan olumlu maddeler $(2,4,7,10,11,14$, $15,17,20,22,25,27)$ 'kesinlikle katıllyorum' seçeneğinden başlayarak 1'den 5'e doğru, olumsuz maddeler $(1,3,5,6$, $8,9,12,13,16,18,19,21,23,24,26)$ ise 'kesinlikle kat1liyorum' seçeneğinden başlayarak 5'ten 1'e doğru puanlanmıştır. Ölçekten alınan toplam puanın artması ön yargı düzeyinin arttığını göstermektedir. Ölçeğin değerlendirilmesinde ölçeği geliştirenlerin kullandığı kesim noktalarına göre sınıflama yapılmış olup, buna göre ölçekten 68,00 puan ve altı alanlar ön yargısız, 68,01-84,99 arasında puan alanlar ön yargıya eğilimli, 85,00 ve üzeri puan alanlar ise ön yargılı olarak değerlendirilmiştir (19). Sosyo-demografik özellikler, yaşam tarzı alışkanlıkları, antropometrik ölçümler ya da diğer etmenlere göre obezite ön yargı durumunun karşılaştırılması toplam puana göre yapılmıştır.

\section{Yeme Tutum Testi-40}

Bireylerin yeme tutumları ile obezite ön yargı durumu arasında ilişki bulunup bulunmadığının incelenmesi amaciyla kullanilan Yeme Tutum Testi-40, Garner ve Garfinkel tarafindan 1979 yllında geliştirilmiştir (20). Toplam 40 maddeden oluşan ölçeğin amacı anorektik hastalarda yemek yeme ile ilgili tutum ve davranışları, sağlıklı bireylerde ise olası anorektik belirtileri değerlendirmektir. Ölçeğin Türkçe geçerlik ve güvenirlik çalışması Savaşır ve Erol tarafından 1989 yilında gerçekleştirilmiştir (21). Ölçek "daima", "çok sık", "sık sık", "bazen", "nadiren” ve "hiçbir zaman" seçeneklerinden oluşan 6'lı likert formundadır. Ölçeğin 1, 18, 19, 23, 27 ve 39. maddeleri için bazen 1 puan, nadiren 2 puan, hiçbir zaman 3 puan ve diğer seçenekler ise 0 puan olarak değerlendirilmektedir. Ölçeğin diğer maddeleri için ise daima 3 puan, çok sık 2 puan, sık sık ise 1 puan olarak hesaplanmaktadır. Ölçeğin kesme noktası 30 puan olup; ölçekten 30 ve üzerinde puan alanlar "yeme bozukluğu riski yüksek” olarak tanımlanmaktadır (21).

\section{Verilerin Analizi}

Verilerin değerlendirilmesinde SPSS (Statistical Package for the Social Sciences) versiyon 26.0 istatistik paket programı kullanılmıştır. Nitel veriler sayı ve yüzde; sürekli sayısal veriler ortalama \pm standart sapma veya medyan (25-75. persentil) olarak sunulmuştur. Obezite ön yargı ölçeği puanlarının normallik varsayımları Kolmogorov-Smirnov testi ile incelenmiş ve normal dağılmadığı görülmüştür $(p<0,05)$. $\mathrm{Bu}$ nedenle iki grup karşılaştırmalarında Mann-Whitney $\mathrm{U}$, ikiden fazla grup karşılaştırmalarında ise Kruskal-Wallis testi kullanılmıştır. Gruplar arasında anlamlı farklılık bulunması durumunda post-hoc karşılaştırmalar Bonferroni-Dunn testi ile değerlendirilmiştir. Kategorik verilerin karşlaştırılması ki-kare testi ile yapılmıştır. Tüm verilerin analizlerinde anlamlılık düzeyi $p<0,05$ olarak kabul edilmiştir.

\section{BULGULAR}

Araştırmaya katılan bireylerin bazı genel özellikleri Tablo 1'de sunulmuştur. Buna göre araştırmaya katılan öğrencile-

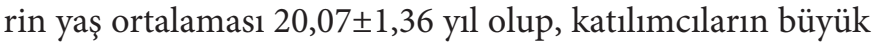
çoğunluğu kadındır $(\% 80,4)$. Öğrencilerin \%37,0'si $(n=280)$ hemşirelik, \%32,8'i ( $\mathrm{n}=248$ ) beslenme ve diyetetik, \%30,2'si $(\mathrm{n}=228)$ fizyoterapi ve rehabilitasyon bölümünde öğrenim görmektedir. Katılımcıların BKİ ortalamaları 21,57 $\pm 3,23$ $\mathrm{kg} / \mathrm{m}^{2}$ olarak saptanmıştır. Öğrencilerin yarısından fazlası $(\% 55,8)$ haftada en az bir kez fiziksel aktivite yaptığını ifade etmiştir. Düzenli bir diyet uygulayanların oranı ise \%12,6 ( $\mathrm{n}=95)$ olarak bulunmuştur (Tablo 1).

Araştırmaya katılan öğrencilerin GAMS-27 Obezite ön yargı ölçeği puan ortalaması 85,28 $\pm 9,98$ (min-max: 41,00-113,00) 
Tablo 1: Öğrencilerin sosyo-demografik ve yaşam tarzı özelliklerine ilişkin bazı bilgiler.

\begin{tabular}{lc}
\hline Özellikler & $\overline{\mathbf{X}} \pm$ SS \\
\hline Yaş $(\mathrm{yl})$ & $20,07 \pm 1,36$ \\
\hline BKİ $\left(\mathrm{kg} / \mathrm{m}^{2}\right)$ & $21,57 \pm 3,23$ \\
\hline & $\mathbf{n}(\%)$ \\
\hline Cinsiyet & $608(80,4)$ \\
\hline Kadın & $148(19,6)$ \\
\hline Erkek & \\
\hline Bölüm & $280(37,0)$ \\
\hline Hemşirelik & $248(32,8)$ \\
\hline Beslenme ve Diyetetik & $228(30,2)$ \\
\hline Fizyoterapi ve Rehabilitasyon & \\
\hline Öğrenim Gördüğ̈̈ Sınıf & $202(26,7)$ \\
\hline 1. sinıf & $216(28,6)$ \\
\hline 2. sinıf & $148(19,6)$ \\
\hline 3. sinıf & $190(25,1)$ \\
\hline 4. sinıf & \\
\hline Fiziksel Aktivite Durumu & $422(55,8)$ \\
\hline Yapıyor & $334(44,2)$ \\
\hline Yapmıyor & $95(12,6)$ \\
\hline Diyet Uygulama Durumu & $661(87,4)$ \\
\hline Evet & \\
\hline Hayır & \\
\hline
\end{tabular}

olarak belirlenmiş olup, buna göre katılımcıların \%53,6's1 $(n=405)$ obeziteye karşı ön yargıll, \%41,1'i $(n=311)$ ön yargıya eğilimli ve $\% 5,3$ 'ü ( $n=40)$ ön yargısız bulunmuştur. Öğrencilerin, obezite ön yargı durumlarına yönelik kendi değerlendirmeleri ile ölçekten alınan puanlar karşılaştırılmış ve kendilerini obezitesi olan bireylere karşı ön yargılı olarak değerlendirenlerin, obezite ön yargı ölçeği puanları [94,00 $(88,00-100,00)]$, kendilerini ön yargisız $[87,00(81,00-94,00)]$ ve kararsız $[84,00(79,00-90,00)]$ olarak değerlendirenden anlamlı olarak daha yüksek bulunmuştur $(p<0,01)$ Buna rağmen, ölçekten alınan puana göre ön yargılı olarak sınıflanan bireylerin sadece \%7,2'si $(n=29)$ kendilerini ön yargilı olarak değerlendirmekte olup, \%68,4'ü $(\mathrm{n}=277)$ kendilerini ön yargısız olarak değerlendirmiştir (Şekil 1).

Katılımcıların GAMS-27 Obezite ön yargı ölçeği maddelerine verdiklerin yanitların ortalaması ve her bir maddeye" katılıyorum ya da kesinlikle katılıyorum" diyenlerin yüzdesi Tablo 2'de sunulmuştur. Buna göre obez bireyler "hastalıklara yatkındır" (\%85,6), "çabuk yorulurlar" (\%83,2), "hareket yetenekleri kısitlıdır" $(\% 82,4)$ ve "hareketlerinde yavaștırlar" $(\% 77,2)$ maddelerinin bireylerin en fazla katıldığı maddeler olduğu saptanmıştır. Obezitesi olan bireyler "bencildir" (\%4,1), "sağlıklı görünürler" (\%7,8), "çekicidirler" $(\% 8,9)$ ifadelerinin ise bireylerin en az katıldığ ifadeler olduğu belirlenmiştir.

Katılımcıların sosyo-demografik özelliklerine göre obezite ön yargı ölçeği ortanca puanları Tablo 3'te sunulmuştur. Cinsiyete göre obezite ön yargı ölçeği puanlarında anlamlı

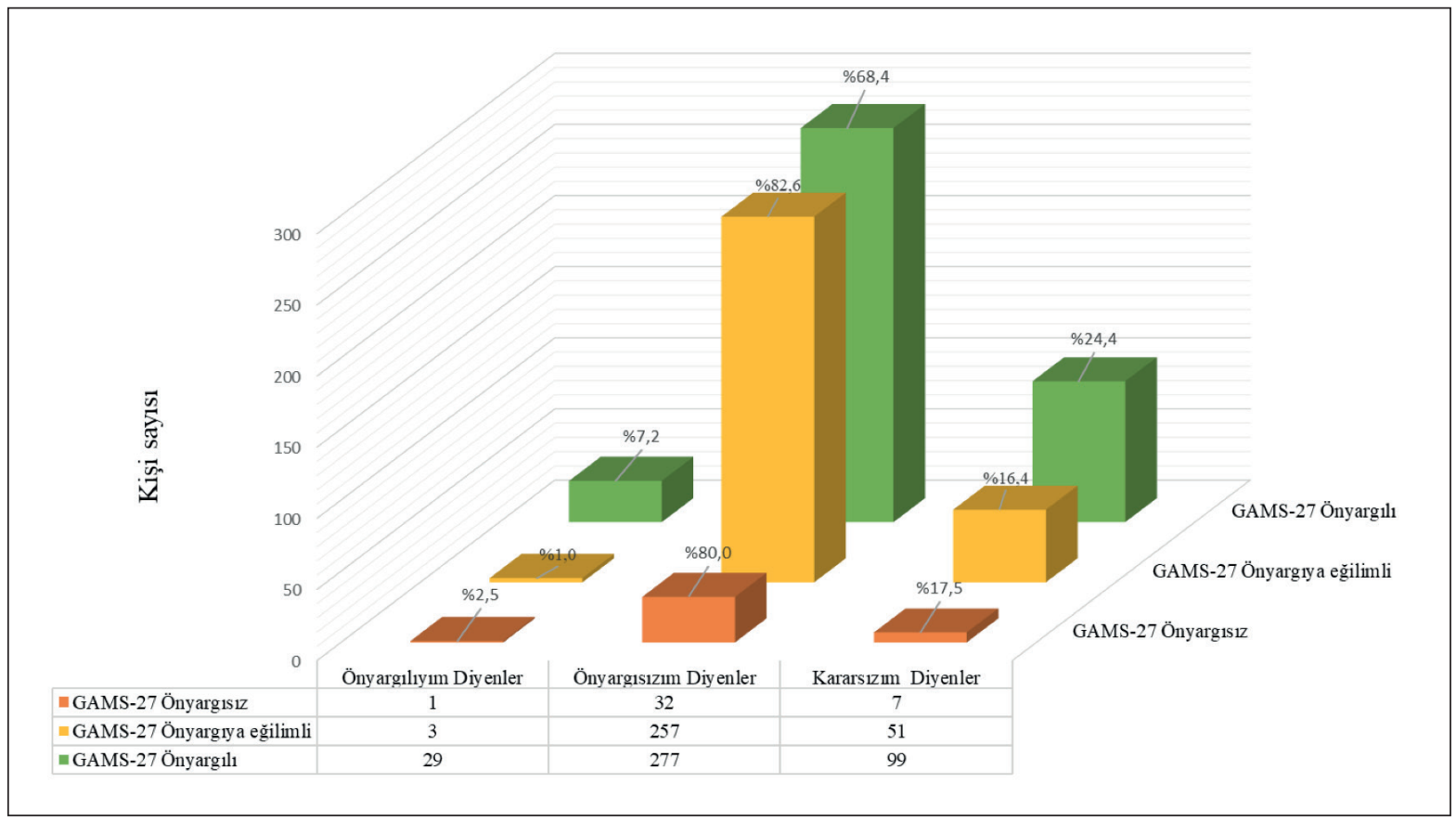

Şekil 1. Öğrencilerin obezite ön yargısına ilişkin kendi değerlendirmeleri ile GAMS-27 obezite ön yargı ölçeği sınıflamalarına göre dağılımlarının karşılaştırılması (Yüzdeler GAMS-27 Obezite ön yargı Ölçeği kategorilerine göre hesaplanmıştır.) 
bir farklılık bulunmadığı saptanmıştır $(p=0,331)$. Obezite ön yargısı durumu bölümlere göre değerlendirildiğinde, beslenme ve diyetetik öğrencilerinin ortanca puanları $[(87,50$ $(81,00-93,00)]$, hemşirelik bölümü $[(83,50(78,00-90,00)]$ ve fizyoterapi ve rehabilitasyon bölümü $[(86,00(79,00-91,00)]$ öğrencilerine göre anlamlı olarak daha yüksek bulunmuştur $(p<0,001)$. Obezite ön yargı puanlarının, öğrenim görülen sınıfa göre değişiklik gösterdiği saptanmış olup, ikinci ve dördüncü sınıf öğrencilerinin ölçekten aldıkları ortanca puan değerleri birinci sınıftaki öğrencilerden daha yüksek bulunmuştur ( $p=0,002)$. Gelir durumuna, aile bireylerinde obezite varlığına, fiziksel aktivite yapma ve şu andaki ya da geçmișteki diyet deneyimine göre obezite ön yargısı puanlarının farklılık göstermediği belirlenmiştir (her biri için $\mathrm{p}>0,05)$. Öğrencilerin BKİ kategorilerine göre obezite ön yargıları değerlendirildiğinde, zayıf, normal ve hafif kilolu olan öğrencilerin ortanca puanlarının obezitesi olan öğrencilere kıyasla anlamlı olarak daha yüksek olduğu belirlenmiştir $(p=0,001)$ (Tablo 3).

Öğrencilerin beden algıları ve yeme tutumlarına göre obezite ön yargıları Tablo 4'te verilmiştir. Fiziksel görünümünden memnun olan ve olmayan öğrencilerin obezite ön yargı ölçeği puanlarının benzer olduğu belirlenmiştir $(\mathrm{p}=0,888)$. Kendi vücut ağırlıklarını zayıf, normal ya da

Tablo 2: GAMS-27 Obezite ön yargı Ölçeği maddelerinin tanımlayıcı istatistikleri.

\begin{tabular}{|c|c|c|c|}
\hline $\begin{array}{l}\text { Ölçek } \\
\text { Maddeleri }\end{array}$ & Obez Kişiler & $\bar{x} \pm \mathrm{SS}$ & $\begin{array}{c}\text { Katılıyorum ya da } \\
\text { kesinlikle katılıyorum } \\
\text { cevabı verenler }(\%)\end{array}$ \\
\hline GAMS27-6 & Hastalıklara yatkındırlar & $1,80 \pm 0,87$ & 85,6 \\
\hline GAMS27-21 & Çabuk yorulurlar & $1,96 \pm 0,83$ & 83,2 \\
\hline GAMS27-12 & Hareket yetenekleri kısıtlıdır & $1,99 \pm 0,88$ & 82,4 \\
\hline GAMS27-23 & Hareketlerinde yavaştırlar & $2,07 \pm 0,82$ & 77,2 \\
\hline GAMS27-16 & Hareket etmeyi sevmezler & $2,43 \pm 0,98$ & 59,7 \\
\hline GAMS27-18 & Yaşam kaliteleri düşüktür & $2,44 \pm 0,96$ & 58,3 \\
\hline GAMS27-27 & Cana yakındırlar & $2,55 \pm 0,76$ & 42,1 \\
\hline GAMS27-14 & Sempatiktirler & $2,59 \pm 0,86$ & 44,8 \\
\hline GAMS27-5 & İradesizdirler & $2,62 \pm 1,06$ & 51,7 \\
\hline GAMS27-4 & Güler yüzlüdürler & $2,67 \pm 0,83$ & 39,8 \\
\hline GAMS27-2 & Güzel yüzlüdürler & $2,71 \pm 0,85$ & 38,2 \\
\hline GAMS27-24 & Tembeldirler & $2,71 \pm 0,97$ & 39,8 \\
\hline GAMS27-10 & Misafirperverdirler & $2,74 \pm 0,79$ & 32,5 \\
\hline GAMS27-25 & Güzel yemek yaparlar & $2,76 \pm 0,77$ & 27,4 \\
\hline GAMS27-22 & İyi dinleyicidirler & $2,77 \pm 0,72$ & 28,4 \\
\hline GAMS27-19 & Olduğundan daha yaşlı görünürler & $2,85 \pm 0,96$ & 36,0 \\
\hline GAMS27-3 & Estetik değildirler & $2,92 \pm 1,10$ & 40,9 \\
\hline GAMS27-13 & Ter kokarlar & $2,96 \pm 0,96$ & 30,3 \\
\hline GAMS27-26 & Görünümlerinden dolayı duygusal ilişkilerde tercih edilmezler & $2,98 \pm 0,97$ & 30,4 \\
\hline GAMS27-20 & Sosyal ilişkileri güçlüdür & $2,99 \pm 0,74$ & 18,8 \\
\hline GAMS27-8 & Toplumda yemek yemekten hoşlanmazlar & $3,14 \pm 0,95$ & 22,8 \\
\hline GAMS27-7 & Mutludurlar & $3,22 \pm 0,82$ & 13,2 \\
\hline GAMS27-17 & Özgüvenlidirler & $3,26 \pm 0,84$ & 12,8 \\
\hline GAMS27-9 & Korkaktırlar & $3,42 \pm 0,88$ & 11,6 \\
\hline GAMS27-11 & Çekicidirler & $3,44 \pm 0,84$ & 8,9 \\
\hline GAMS27-15 & Sağlıklı görünürler & $3,97 \pm 0,96$ & 7,8 \\
\hline GAMS27-1 & Bencildirler & $4,12 \pm 0,89$ & 4,1 \\
\hline
\end{tabular}

1: Kesinlikle katılıyorum, 2: Katılıyorum, 3:Kararsızım, 4: Katılmıyorum, 5: Kesinlikle katılmıyorum. 
Tablo 3: Öğrencilerin sosyo-demografik ve bazı yaşam tarzı özellikleri ile obezite ön yargı ölçeği puanlarının karşılaştırılması.

\begin{tabular}{|c|c|c|c|}
\hline Değişken & $\mathbf{n}$ & $\begin{array}{c}\text { Medyan } \\
\text { (25-75. persentil) }\end{array}$ & $\mathbf{p}$ \\
\hline \multicolumn{4}{|l|}{ Cinsiyet } \\
\hline Kadın & 608 & $85,00(80,00-91,00)$ & \multirow{2}{*}{0,331} \\
\hline Erkek & 148 & $87,00(79,50-93,00)$ & \\
\hline \multicolumn{4}{|l|}{ Bölüm } \\
\hline Hemşirelik & 280 & $83,50(78,00-90,00)^{\mathrm{a}}$ & \multirow{3}{*}{$<0,001$} \\
\hline Beslenme ve Diyetetik & 248 & $87,50(81,00-93,00)^{\mathrm{b}}$ & \\
\hline Fizyoterapi ve Rehabilitasyon & 228 & $86,00(79,00-91,00)^{\mathrm{a}}$ & \\
\hline \multicolumn{4}{|l|}{ Sinif } \\
\hline 1. sinif & 202 & $84,00(78,00-89,00)^{\mathrm{a}}$ & \multirow{4}{*}{0,002} \\
\hline 2. sinif & 216 & $86,50(81,00-93,00)^{\mathrm{b}}$ & \\
\hline 3. sinif & 148 & $84,50(80,00-91,00)^{\mathrm{a}, \mathrm{b}}$ & \\
\hline 4. sinif & 190 & $87,00(81,00-93,00)^{\mathrm{b}}$ & \\
\hline \multicolumn{4}{|l|}{ Gelir Durumu } \\
\hline Kötü & 194 & $84,00(78,00-89,00)$ & \multirow{3}{*}{0,447} \\
\hline Orta & 526 & $86,00(80,00-91,00)$ & \\
\hline İyi & 36 & $84,00(80,00-91,00)$ & \\
\hline \multicolumn{4}{|l|}{ Aile Obezite Varlığı } \\
\hline Var & 403 & $84,00(79,00-91,00)$ & \multirow{2}{*}{0,103} \\
\hline Yok & 353 & $87,00(81,00-92,00)$ & \\
\hline \multicolumn{4}{|l|}{ Fiziksel Aktivite Durumu } \\
\hline Yapiyor & 451 & $85,00(80,00-91,00)$ & \multirow{2}{*}{0,390} \\
\hline Yapmiyor & 305 & $86,00(80,00-92,00)$ & \\
\hline \multicolumn{4}{|l|}{ Diyet Uygulama Durumu } \\
\hline Evet & 95 & $88,00(80,00-93,00)$ & \multirow{2}{*}{0,265} \\
\hline Hayır & 661 & $85,00(80,00-91,00)$ & \\
\hline \multicolumn{4}{|l|}{ Geçmişte Diyet Deneyimi } \\
\hline Evet & 265 & $86,00(80,00-90,00)$ & \multirow{2}{*}{0,383} \\
\hline Hayır & 491 & $85,00(80,00-92,00)$ & \\
\hline \multicolumn{4}{|l|}{ BKİ } \\
\hline Zaylf & 124 & $87,00(81,00-93,00)^{a}$ & \multirow{4}{*}{0,001} \\
\hline Normal & 536 & $85,00(80,00-91,00)^{\mathrm{a}}$ & \\
\hline Kilolu & 77 & $87,00(79,00-91,00)^{a}$ & \\
\hline Obez & 19 & $80,00(73,50-82,00)^{\mathrm{b}}$ & \\
\hline
\end{tabular}

p değerleri, Mann-Whitney U ya da Kruskal Wallis ile hesaplanmıştır. Post-hoc karşılaştırmalar Bonferroni Dunn testi ile yapılmıştır. Obezite ön yargı ölçeği puan ortancalarının yanında bulunan farklı harfler ortalamaların istatistiksel olarak farklı olduğunu gösterir.

şişman olarak değerlendiren öğrencilerin obezite ön yarg1 ölçeği puanları arasında da farklılık tespit edilmemiştir $(\mathrm{p}=0,305)$. Buna karşın, yaşamının herhangi bir döneminde kendini şişman bulan öğrencilerde diğer öğrencilere kıyasla obezite ön yargı ölçeğinden alınan puan daha düşük bulunmuştur $(p=0,005)$. Öğrencilerin yeme tutumlarına göre obezite ön yargı puanlarının farklılık göstermediği saptanmiştır $(p=0,206)$ (Tablo 4). 
Tablo 4: Öğrencilerin beden algıları ve yeme tutumları ile obezite ön yargı ölçeği puanlarının karşılaştırılması.

\begin{tabular}{|c|c|c|c|}
\hline Değerlendirme & $\mathbf{n}$ & $\begin{array}{c}\text { Medyan } \\
\text { (25-75. persentil) }\end{array}$ & $\mathbf{p}$ \\
\hline \multicolumn{4}{|l|}{ Fiziksel Görünümü } \\
\hline Memnunum & 530 & $85,00(80,00-91,00)$ & \multirow{2}{*}{0,888} \\
\hline Değilim & 226 & $86,00(80,00-91,00)$ & \\
\hline \multicolumn{4}{|c|}{ Vücut Ağırlığı Hakkındaki Düşünce } \\
\hline Zayif & 116 & $86,00(81,00-93,00)$ & \multirow{3}{*}{0,305} \\
\hline Normal & 512 & $86,00(80,00-91,00)$ & \\
\hline Şişman & 128 & $85,00(78,00-90,00)$ & \\
\hline \multicolumn{4}{|l|}{ Kendini Şişman Bulduğu Dönem } \\
\hline Oldu & 450 & $85,00(79,00-91,00)$ & \multirow{2}{*}{0,005} \\
\hline Olmadi & 306 & $86,00(81,00-93,00)$ & \\
\hline \multicolumn{4}{|c|}{ Sağlıklı Beslenmeye Yönelik Düşünce } \\
\hline Evet & 288 & $86,00(80,00-92,00)$ & \multirow{2}{*}{0,189} \\
\hline Hayır & 468 & $85,00(79,00-91,00)$ & \\
\hline \multicolumn{4}{|c|}{ Yeme Tutum Testi Değerlendirmesi } \\
\hline Yeme tutum bozukluğu riski var & 51 & $89,00(79,50-93,50)$ & \multirow{2}{*}{0,206} \\
\hline Yeme tutum bozukluğu riski yok & 705 & $85,00(80,00-91,00)$ & \\
\hline
\end{tabular}

p değerleri, Mann-Whitney U ya da Kruskal Wallis ile hesaplanmıştır.

\section{TARTIŞMA}

Bu çalışmaya katılan ve sağlık bilimleri fakültesinde eğitimlerini sürdüren öğrencilerin \%53,6'sının obeziteye karşı ön yargıll, \%41,1'inin ön yargıya eğilimli olduğu belirlenmiştir. Ayrıca obezite ön yargı puanlarının beslenme ve diyetetik bölümü öğrencilerinde diğer bölümlere göre daha yüksek olduğu belirlenmiştir.

Sağlık çalışanları, obezitesi olan bireylerin bakımı ve tedavisinde aktif rol alan ve hastalarının yaşam kalitesini artırmaya çalışan meslek profesyonelleridir. Buna karşın, sağlık ile ilişkili alanlarda okuyan öğrenciler ya da sağlık profesyonelleri ile yapılan araştırmalar, hem ülkemizde hem de Dünya'da obezite ön yargısının yaygın olabileceğini göstermektedir (15,22-24). Ülkemizde yürütülmüş bir çalışmada, hemşirelerde ve hemşirelik bölümü öğrencilerinde obezitesi olan bireylere yönelik olumsuz tutumların yaygın olduğu saptanmıştır. Olumsuz tutumların hemşirelerde, hemşirelik öğrencilerine göre daha fazla olduğu bildirilmiştir (15). Dünya'daki araştırmalarda obezite ön yargısı genellikle 14 maddeden oluşan "yağ (ağırlık) fobisi ölçeği” (fat-phobia scale) ile değerlendirilmektedir (25). Ölçekten alınan toplam puan ortalamasının $\geq 2,5$ üzerinde olması olumsuz tutum; altında olması ise olumlu tutum ile ilişkilendirilmektedir. Bu ölçek kullanılarak Meksika'da beslenme eğitimi alan öğrenciler ile yapılan bir çalışmada, öğrencilerin \%88'inin obezitesi olan bireylere yönelik olumsuz tutumlara sahip olduğu saptanmıştır (23). İngiltere'de doktorlar, hemşireler ve diyetisyenler ile yürütülen bir çalışmada, katılımciların ( $\mathrm{n}=1130)$ sadece \%1,4'ünün olumlu ya da nötr tutuma sahip olduğu belirlenmiştir (24). Farklı ülkelerde yürütülmüş araştırmalarda da benzer bulgular rapor edilmiştir $(26,27)$. Obeziteye yönelik olumsuz tutumlarının hastaları motive ederek yaşam tarzı değişikliklerini tetikleyebileceği öne sürülse de, araştırmalar bu durumun bireylerde tam aksi bir etki oluşturduğunu göstermektedir (28). Ağırlık damgalaması daha sağlıksız yaşam tarzı alışkanlıkları ile ilişkili olup; yargılandığını ya da dışlandığını hisseden birey ağırlık kaybı sağlamak için daha az girişimde bulunmakta ya da daha az başarılı olmaktadır $(11,29)$. Bu nedenle bu bulgular doğrultusunda, sağlık alanında okuyan öğrencilerin ve sağllk profesyonellerinin obeziteye yönelik olumsuz tutum ve davranışlarını azaltmak üzere çeşitli girişimlere ihtiyaç olduğu söylenebilir.

Obeziteye yönelik ön yargıların açı ya da örtük olarak gözlenebileceği bildirilmiştir. Bireylerin vücut ağırlığı fazla olan kişilere bilinçli olarak olumsuz tutumlarını ifade etmeleri açık ön yargı olarak değerlendirilirken, örtük ön yarg1lar bilinçli farkındalığın ötesindeki ön yargılardır. Örtük ön yargılar, çevresel bir işaret ile otomatik olarak aktifleşen 
ve bireyin farkında olmadığı ön yargılardır (3). Çevrimiçi ortamda yürütülen 4732 birinci sinıf tıp öğrencisinin katıldığ bir araştırmada, öğrencilerin \%67'sinin açık, \%74'ünün örtük ağırlık ön yargısı olduğu belirlenmiştir (30). Bu araştırmada, kendini ön yargılı olarak değerlendiren bireylerin obezite ön yargı ölçeği puanlarının kendilerini ön yarg1sız olarak tanımlayanlardan yüksek olması açık ön yargı olarak düşünülebilir. Buna karşın, ölçekten alınan puana göre obeziteye yönelik ön yargısı olduğu saptanan bireylerin $\% 68,4$ 'ü kendilerini ön yargısız olarak değerlendirmektedir. Her ne kadar bu araştırma örtük ön yargıların incelenmesine yönelik bir tasarıma sahip olmasa da, bu durum bireylerin kendilerini ön yargılı olarak ifade etmekten kaçınmalarının yanı sıra örtük ön yargılarının da bir göstergesi olarak değerlendirilebilir.

Obeziteye yönelik olumsuz yargıların önemli nedenlerinden biri obezitenin bireyin kontrolünde olduğu düşüncesi ve vücut ağırlığındaki artışın bir tür irade eksikliği ile ilişkilendirilmesidir. Obeziteye ilişkin olumsuz tutum ve düşünceler, obezitenin genetik, biyolojik ve çevresel etmenlerin dâhil olduğu multifaktöriyel bir hastalık olduğunun göz ardı edilmesi ve obezitenin bir seçim olduğunun düşünülmesi ile artmaktadır (14,24,26,31). Bu durum, fazla kilosu ya da obezitesi olan bireylerin genellikle tembel, iradesiz, cesareti ve öz-disiplini olmayan bireyler olarak tanımlanmasına neden olmaktadır (14). Diyetetik öğrencileri ile yapılan bir çalışmada $(\mathrm{n}=182)$, öğrencilerin \%80'inin obezitesi olan bireyleri güvenilmez olarak değerlendirdiği belirlenmiştir. Buna ilave olarak, katılımcıların çoğunluğu vücut ağırlığı fazla olan bireyleri inaktif (\%77), düșük özgüveni olan (\%75), dayanıksı (\%72), yavaş (\%68), öz-kontrolü zayıf (\%65), çekici olmayan (\%54), iradesiz (\%41) ve tembel (\%41) olarak tanımlamıştır (32). Bu çalışma da, katılımciların yarısından fazlası obezitesi olan bireyleri hastalıklara yatkın, çabuk yorulan, hareket yetenekleri kısıtll, yavaş, hareket etmeyi sevmeyen, yaşam kaliteleri düşük ve iradesiz bireyler olarak değerlendirmiştir. Obezitenin genetik, epigenetik ve çevresel etmenlerin bir kombinasyonu olduğuna ilişkin farkındalığın artırılmasının ve eğitimlerde obezitenin basit bir seçim olmadığının vurgulanmasının, ön yargıların azaltılmasında önemli bir strateji olabileceği bildirilmiştir (14).

Sağlık bilimleri alanında çalışan ve farklı mesleklerle uğraşan bireylerin obeziteye yönelik tutumları karşılaştırıldığında, hemşireler, beslenme uzmanları ya da diğer sağlık profesyonellerine göre doktorlarda ağırlık fobisinin daha fazla olduğu belirlenmiştir $(24,26,33)$. Bu araştırmada, hemşirelik, beslenme ve diyetetik, fizyoterapi ve rehabilitasyon bölümleri karşılaştırıldığında obezite ön yargı puan ortalamalarının beslenme ve diyetetik öğrencilerinde daha yüksek olduğu belirlenmiştir. Özellikle ülkemizde, diyetisyenlerin en fazla hizmet sunduğu alanlardan birinin obezite olduğu düşünüldüğünde, beslenme ve diyetetik öğrencilerinde ön yargı düzeyinin yüksek olmasının önemli bir bulgu olduğu söylenebilir. Araştırmalar diyetisyenlerin vücut ağırlığına yönelik olumsuz tutum ve düşüncelere sahip olmalarının, tıbbi beslenme tedavisine yönelik aldıkları kararları ve mesleki uygulamaları etkileyebileceğini göstermektedir $(27,32)$. Aslında, obeziteye yönelik ön yargıların hastalık hakkında bilgi sahibi oldukça azalması beklenmektedir. $\mathrm{Bu}$ nedenle, öğrencilerin okudukları sınıf ilerledikçe ön yarg1ların azalması beklenebilir. Nitekim, Swift ve ark.nın çalışmasında hemşirelik ve diyetetik öğrencilerinde yağ fobisinin üniversitenin ilk yılına kıyasla son sinıf öğrencilerinde daha az olduğu belirlenmiştir (24). Buna karşın Puhl ve ark. diyetetik eğitiminde ağırlık damgalamasının azaltılmasına yönelik müdahalelere ihtiyaç olduğunu vurgulamıştır (32). Bu çalışmada da, yıllar içerisinde ön yargı puanlarında bir azalma olmayıp, tam ters bir bulgu olarak ilk yıldaki öğrencilerin puan ortalamalarının anlamlı olarak daha düşük olduğu belirlenmiştir. Bu verilerden yola çıkarak, sağlik bilimleri öğrencilerine özellikle de beslenme ve diyetetik programına obezite ön yargısını azaltmaya yönelik içeriklerin eklenmesinin yararlı olabileceği söylenebilir.

Obeziteye yönelik ön yargılar, sosyal kimlik kuramı, ilişkilendirme teorisi ve sosyokültürel kuram gibi çeşitli teoriler ile açıklanmaktadır (30). Sosyal kimlik kuramına göre bireyler kendilerini ait hissettikleri grupları diğerlerinden üstün tutma eğilimi gösterirler. Kendi grubuna ve grup üyelerine karşı sempati duyarken, diğer gruplara yönelik küçümseyici düşünce ve tavırlara sahip olabilir (34). Kurama göre eğer birey "zayıfların" olduğu gruba dâhilse "şişmanlığa" yönelik olumsuz düşünce ve tutumlara sahip olabilir. Nitekim yapılan çalışmalar, hafif şişman ya da şişman olan bireylerde ağırlık fobisinin daha az olduğunu göstermektedir $(15,24,26,31)$. Bu çalıșmada da, obezitesi olan bireylerde obezite ön yargı ölçeği puanlarının daha düşük olması literatürdeki diğer çalışmaları desteklemekte ve sosyal kimlik kuramı ile örtüşmektedir. Kişinin BKİ değerlerine göre sınıflandırılmasının dışında, vücut ağırlığına yönelik kendisini nasıl algıladığı, başka bir ifadeyle kendisini hangi gruba ait hissettiğinin (zayıf, normal, şişman vb) de obeziteye ilişkin düşünce ve tutumlar açısından önemli olabileceği vurgulanmıştır (30). Buna karşın bu araştırmada, bireylerin vücut ağırlığı hakkındaki kendi düşüncelerine göre obezite ön yargı ölçeği puanlarının farklılık göstermediği bulunmuştur. Ancak yaşamın herhangi bir döneminde şişman olduğunu belirten bireylerde obezite ön yargı ölçeği puanlarının daha düşük olduğu belirlenmiştir. 
Cotugna ve Mallick'in yürüttükleri bir müdahale çalışmasinda üniversitede obezite dersi alan öğrencilerin 1 hafta süreyle kalori kısitlı (1200-1500 kkal) bir diyet uygulamalarının ağırlık fobisini azalttığı saptanmıştır (35). Bu çalışmada ise, bireylerin şu andaki ya da geçmişteki diyet yapma deneyimleri veya yeme tutumlarına göre obezite ön yargısı puanlarının farklılık göstermediği bulunmuştur. Cotugna ve Mallick'in çalıșması bir müdahale olduğu ve bireylerin normal beslenme düzenlerinin dışına çıkarak diyet yapmayı deneyimlemeleri obeziteye ilişkin fikirlerin değişmesine yol açmış olabilir. Buna karşın, bu çalışmada yeme tutumlarının kişilerin kendi alışkanları ve tercihleri doğrultusunda sürdürülmesi, obezite ön yargısı ile ilişkili bulunmamasının nedenleri arasinda yer alabilir.

Sonuç olarak bu çalışmada, sağlık bilimleri öğrencilerinde obeziteye yönelik ön yargıların yüksek olduğu saptanmıştır. Obezitesi olanlarda veya yaşamlarında kendilerini şişman buldukları bir dönemi olan bireylerde obezite ön yargısı puanlarının daha düşük olduğu bulunmuștur. Çalıșmanın tek merkezli olması nedeniyle genellenebilirliğinin sınırlı olduğu söylenebilir. Buna karşın, örneklem sayısının yüksekliği ve farklı meslek gruplarını kapsayacak şekilde yürütülmüş olması güçlü yanlarındandır. İlerleyen dönemlerde, ülke profilini yansıtacak çalışmaların yürütülmesi hedeflenebilir. Geleceğin sağlık profesyonellerinin sağlık ile ilgili karar alır ve uygularken ön yargılardan uzak ve akılcı düşünebilmeleri iyi bir sağlık hizmeti sunabilmeleri için elzemdir. Bu nedenle mevcut ön yargıların azaltılabilmesi için ders programlarına farkındalık artırmaya yönelik çeşitli uygulamaların eklenmesinin yararlı olacağı düşünülmektedir.

\section{Etik Kurul Onayı}

Araștırmanın yapılması için gerekli izinler İzmir Kâtip Çelebi Üniversitesi Sosyal Araştırmalar etik kurulundan 07.11.2019 tarihinde alınmıștır (Etik kurul No: 2019.08.04).

Çıkar Çatışması

Yazarlar çıkar çatışmaları olmadığını beyan eder.

Finansal Destek

Finansal bir destek bulunmamaktadır.

Yazarların Makaleye Katkı Beyanı

Fikir/kavram: Ezgi Bellikci Koyu, Şafak Miçooğulları, Tasarım: Ezgi Bellikci Koyu, Şafak Miçooğulları, Denetleme/danışmanlık: Ezgi Bellikci Koyu, Yasemin Karaağaç, Veri toplama ve/veya işleme: Şafak Miçooğulları, Yasemin Karaağaç, Analiz ve/veya yorum: Ezgi Bellikci Koyu, Yasemin Karaağaç, Kaynak taraması: Ezgi Bellikci Koyu, Yasemin Karaağaç, Şafak Miçooğulları, Makelenin Yazılması: Ezgi Bellikci Koyu, Yasemin Karaağaç, Şafak Miçooğulları, Eleştirel inceleme: Ezgi Bellikci Koyu

Teșekkür

Yazarlar, çalışmanın istatistiksel analizlerinin yapılmasına destek olan Doç. Dr. Mustafa Agah TEKİNDAL'a teşekkür eder.

\section{KAYNAKLAR}

1. Bluher M. Obesity: Global epidemiology and pathogenesis. Nat Rev Endocrinol 2019;15(5):288-298.

2. World Health Organization. Weight bias and obesity stigma: considerations for the WHO European Region 2017[Internet]. Accessed July 23, 2020, https://www.euro.who.int/_data/ assets/pdf_file/0017/351026/WeightBias.pdf.

3. Altun S, Ercan A. Obezite ön yarg1sı. Türkiye klinikleri beslenme ve diyetetik-özel konular. 2016;2(1):17-22.

4. Papadopoulos S, Brennan L. Correlates of weight stigma in adults with overweight and obesity: A systematic literature review. Obesity. 2015;23(9):1743-1760.

5. Wu YK, Berry DC. Impact of weight stigma on physiological and psychological health outcomes for overweight and obese adults: A systematic review. J Adv Nurs 2018;74(5):1030-1042.

6. Andreyeva T, Puhl RM, Brownell KD. Changes in perceived weight discrimination among Americans, 1995-1996 through 2004-2006. Obesity. 2008;16(5):1129-1134.

7. Tomiyama AJ, Finch LE, Belsky AC, Buss J, Finley C, Schwartz MB, et al. Weight bias in 2001 versus 2013: Contradictory attitudes among obesity researchers and health professionals. Obesity. 2015;23(1):46-53.

8. Sikorski C, Spahlholz J, Hartlev M, Riedel-Heller SG. Weightbased discrimination: An ubiquitary phenomenon? Int J Obes (Lond). 2016;40(2):333-337.

9. Spahlholz J, Baer N, König HH, Riedel-Heller SG, LuckSikorski C. Obesity and discrimination - a systematic review and meta-analysis of observational studies. Obes Rev. 2016;17(1):43-55.

10. Nutter S, Ireland A, Alberga AS, Brun I, Lefebvre D, Hayden $\mathrm{KA}$, et al. Weight bias in educational settings: A systematic review. Curr Obes Rep. 2019;8(2):185-200.

11. Phelan SM, Burgess DJ, Yeazel MW, Hellerstedt WL, Griffin JM, van Ryn M. Impact of weight bias and stigma on quality of care and outcomes for patients with obesity. Obes Rev. 2015;16(4):319-326

12. Giel KE, Thiel A, Teufel M, Mayer J, Zipfel S. Weight bias in work settings- a qualitative review. Obes Facts. 2010;3(1):3340.

13. Sievert K, Lobstein T, Baker P. Stigmatizing images in the media- a cross-national survey. Clin Obes. 2018;8(6):407-410.

14. Rubino F, Puhl RM, Cummings DE, Eckel RH, Ryan DH, Mechanick JI, et al. Joint international consensus statement for ending stigma of obesity. Nat Med. 2020;26(4):485-497.

15. Yılmaz H, Yabanc1 Ayhan N. Is there prejudice against obese persons among health professionals? A sample of student nurses and registered nurses. Perspect Psychiatr Care. 2019;55(2):262-268

16. Kadığlu B, Uncu F, Nazik F, Sönmez M. İki farklı üniversitede eğitim gören üniversite öğrencilerinin kilofobi ve fiziksel aktivite düzeyleri. Adıyaman Üniv Sağlık Bilim Derg. 2015;1:77-86. 
17. Altinayak SÖ, Gür EY, Apay SE, Özkan H. Ebelik öğrencilerinin obez gebelere karşı önyargısı. Anadolu Hemşirelik ve Sağlık Bilimleri Dergisi. 2017;20:201-207.

18. World Health Organization. Body Mass Index-BMI[Internet]. (Accessed July 15, 2020, https://www.euro.who.int/en/healthtopics/disease-prevention/nutrition/a-healthy-lifestyle/bodymass-index-bmi.)

19. Ercan A, Ok MA, Kızıltan G, Altun S. Sağlık bilimleri öğrencileri için obezite önyargı ölçeğinin geliştirilmesi: GAMS 27-obezite önyargı ölçeği. Uluslararası Hakemli Beslenme Araştırmaları Dergisi. 2015;3(2):29-43.

20. Garner DM, Garfinkel PE. The eating attitudes test: An index of the symptoms of anorexia nervosa. Psychol Med. 1979;9(2):273-279.

21. Savaşır I, Erol N. Yeme tutum testi: Anoreksiya nervoza belirtileri indeksi. Psikoloji Dergisi. 1989;7:19-25.

22. Poon MY, Tarrant M. Obesity: Attitudes of undergraduate student nurses and registered nurses. J Clin Nurs. 2009;18(16):2355-2365.

23. Bacardía Gascón M, Jiménez-Cruz A, Castillo-Ruiz O, BezaresSarmiento Vdel R, León-González JM. Fat phobia in mexican nutrition students. Nutr Hosp. 2015;32(6):2956-2957.

24. Swift JA, Hanlon S, El-Redy L, Puhl RM, Glazebrook C. Weight bias among UK trainee dietitians, doctors, nurses and nutritionists. J Hum Nutr Diet. 2013;26(4):395-402.

25. Bacon J, Scheltema K, Robinson B. Fat phobia scale revisited: The short form. Int J Obes. 2001;25:252-257.

26. Soto L, Armendariz-Anguiano AL, Bacardí-Gascón M, Jiménez Cruz A. Beliefs, attitudes and phobias among Mexican medical and psychology students towards people with obesity. Nutr Hosp. 2014;30(1):37-41.
27. Diversi TM, Hughes R, Burke KJ. The prevalence and practice impact of weight bias amongst Australian dietitians. Obes Sci Pract. 2016;2(4):456-465.

28. Puhl RM, Heuer CA. Obesity stigma: Important considerations for public health. Am J Public Health 2010;100(6):1019-1028.

29. Puhl R, Suh Y. Health consequences of weight stigma: Implications for obesity prevention and treatment. Curr Obes Rep. 2015;4(2):182-190.

30. Phelan SM, Dovidio JF, Puhl RM, Burgess DJ, Nelson DB, Yeazel MW, Hardeman R, Perry S, Ryn MV. Implicit and explicit weight bias in a national sample of 4,732 medical students: The medical student CHANGES study. Obesity (Silver Spring). 2014;22(4):1201-1208.

31. Wise FM, Harris DW, Olver JH. Attitudes to obesity among rehabilitation health professionals in Australia. J Allied Health. 2014;43(3):162-168.

32. Puhl R, Wharton C, Heuer C. Weight bias among dietetics students: Implications for treatment practices. J Am Diet Assoc. 2009;109(3):438-444.

33. Sikorski C, Luppa M, Glaesmer H, Brähler E, König HH, Riedel-Heller SG. Attitudes of health care professionals towards female obese patients. Obes Facts. 2013;6(6):512-522.

34. Demirtaş HA. Sosyal kimlik kuramı, temel kavram ve varsayımlar. İletişim Araştırmaları. 2003;1(1):123-144.

35. Cotugna N, Mallick A. Following a calorie-restricted diet may help in reducing healthcare students' fat-phobia. J Community Health. 2010;35(3):321-324. 